\title{
Covid-19 pandemic in central Asia: policy and environmental implications and responses for SMES support in Uzbekistan
}

\author{
Konstantin Kurpayanidi ${ }^{1,2, *}$ and Alisher Abdullaev ${ }^{2}$ \\ ${ }^{1}$ Russian Academy of Natural Sciences, Moscow, Russia \\ ${ }^{2}$ Fergana Polytechnic Institute, Fergana, Uzbekistan
}

\begin{abstract}
Today the economy of Uzbekistan, as well as the majority of other countries of the world, is developing in conditions of uncertainty. On the one hand, it is associated with the consequences of new coronavirus pandemic, and on the other - with the introduction of forced restrictions, which hinder business development. This article deals with the necessity to provide financial support to business during the coronavirus pandemic in developing countries. It shows the impact of measures to support small and medium enterprises on economic development. Finally, it outlines recommendations for additional interventions and further research.
\end{abstract}

\section{Introduction}

The global COVID-19 pandemic is having a significant negative impact on the economies of Central Asia. Trade has been severely disrupted, healthcare systems are coming under strain, and consumption and investment are plummeting. The crisis is affecting key drivers of growth in the region, including migrant remittances, oil and mineral exports, and the service sector. Relatively undiversified structures of production and exports, along with the high level of informality in some countries, have exacerbated a number of challenges that arise as governments respond to the crisis and have put pressure on public finances. Governments in the region have made serious interventions to support the liquidity of households and businesses and most of them are now starting to relax confinement measures. A number of countries have implemented short-term public health, monetary and economic policy measures, especially for small firms and have received emergency assistance from international partners.

Economic forecasts issued over April-June 2020 depict an increasingly negative outlook in terms of the scale of the global economic recession triggered by the pandemic. In its June 2020 Economic Outlook, the OECD projected a 6\% drop in global GDP, and a $7.6 \%$ fall in case of a second pandemic wave by end 2020 (Figure 1), with a double digit decline in some of the most hit countries, followed by a modest recovery of $2.8 \%$ in 2021 [1]. This follows a forecast in late March, which indicated that the initial direct impact of the shutdowns could be a decline in the level of output of between one-fifth to one-quarter in many economies, with consumers' expenditure potentially dropping by around one-third.

*Corresponding author:w7777@mail.ru 
In recent weeks, several other international organizations have issued forecasts on aspects of the economic impact of the coronavirus pandemic. The IMF June 2020 Economic Outlook Update projects a decline in global GDP by 4.9 percent in 2020, 1.9 percentage points below the April forecast, followed by a partial recovery, with growth at 5.4 percent in 2021 [2]. The June 2020 World Investment Report [3] forecasts a decline in global foreign investment by up to $40 \%$ in 2020 , with a further decrease by $5-10 \%$ in 2021 . The ILO estimates the impact of COVID-19 to result in a rise in global unemployment of between 5.3 million ("low" scenario) and 24.7 million ("high" scenario), signaling that "sustaining business operations will be particularly difficult for Small and Medium Enterprises (SMEs)' [4]. The WTO reported a decline in the volume of global merchandise trade in Q1 2020 by 3\% year-on-year, and expects an unpresented decline in Q2 of $18.5 \%$, potentially leading to a drop of $32 \%$ over 2020 [4].

\section{Impact of COVID-19 on the global economy}

The impact of the disease on society and economy can be witnessed from the lockdown of cities all over the world, labor mobility restrictions, travel bans, airline suspensions, and most importantly slowdown of the economy. COVID-19 crisis went global from February 21 to March 24, 2020 and still the number of cases is growing rapidly every day. It is predicted that the COVID-19 outbreak will have major ramifications for global GDP growth [5].

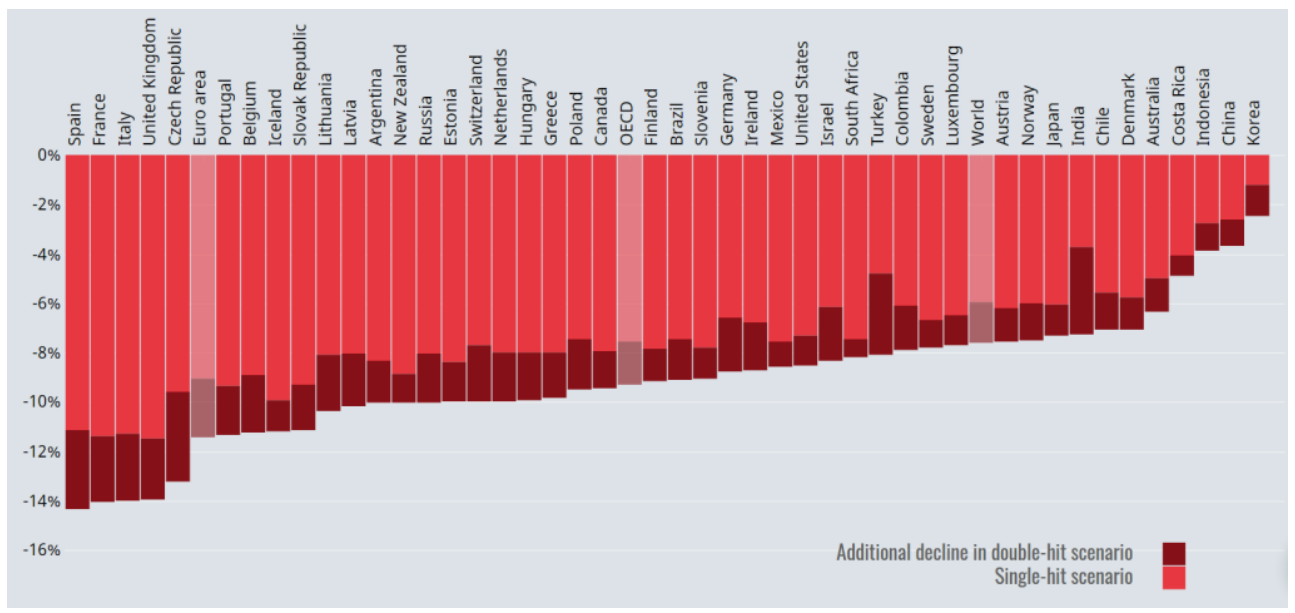

Fig. 1. 2020-Projected change in GDP (Source: OECD Real GDP forecast (indicator) http://www.oecd.org/economic-outlook/june-2020/).

Due to the global outbreak of COVID-19, the global GDP is likely to be affected between $2.3 \%$ to $4.8 \%$ [6]. Additionally, it has also been predicted that the current pandemic outbreak may cause global foreign direct investment to shrink by 5\%-15\% [7]. Further, according to the UNCTAD report, the world needs a support package of up to $\$ 2.5$ trillion to cope with the damage [8]. Hence, based on these statistics, the current global crisis will likely be worse than the 2008 crisis [7].

Further, according to International Labor Organization (ILO), almost 25 million people around the globe could lose their jobs (loss of workers' income of as much as USD 3.4 trillion) [9]. A more recent report of ILO shows that lockdowns (full or partial) measures are influencing $81 \%$ (around 2.7 billion workers) of the total global workers. "It is the worst global crisis since the Second World War". Estimates suggest the U.S. would lose three million jobs by mid-summer in 2020, the trend in Europe and other parts of the world will be 
similar. According to ILO the impact of COVID-19 on the economic output of accommodation and food services, real estate, wholesale and retail trade, repair of motor vehicles and motorcycles is 'high', while utilities, public administration and defense, social work activities, human health, and education is 'low'4 [10].

COVID-19 will have a more profound effect in developing countries that will make it much more difficult for them to implement effective stimulus without facing binding foreign exchange constraints. Most vulnerable countries are those that have weak health infrastructure, heavily dependent on trade and tourism sectors, heavily indebted, and that depend on unstable capital flows. Controlling the COVID-19 outbreak will revive the economy, but the risk of continued financial stress is very high even after 2020. Further, it has also been estimated that poverty is likely to increase by around 11 million people [11]. Although the economic impact of the outbreak is continuing and is increasingly unpredictable, it is clear that the situation in developing economies will get worse before it gets better [8]. According to the United Nations Development Programme (UNDP), income losses in developing countries are likely to exceed \$220 billion [12]. In addition, World Bank in its recent report has predicted that South Asia could face its worst economic performance in 40 years with half of the countries falling into a deep recession [13].

\section{Methodology}

We adopted an exploratory methodology with extensively reviewing the available literature, including policy documents, research papers, and reports in the relevant field. Further, to add empirical evidence, we collected data from small and medium-sized enterprises (SMEs) operating in Uzbekistan. The data were collected by administering an online questionnaire due to various reasons including time and financial constraints, and most importantly, due to COVID-19 outbreak and lockdowns. Many researchers also adopted a similar approach and found it useful as well as time and cost-saving [15]. A descriptive analysis approach is used for data analysis.

\section{Findings and discussion}

The multiple effects of the COVID-19 on commodities, trade and local economies will have a big impact on GDP growth in the region, which is expected to turn negative in 2020 (Table 1). These economic growth rates are likely to be further revised down in the upcoming months, as lockdown measures are very progressively removed and the risk of the second wave can materialize, while global trade forecasts remain bleak with a possible decline of up to a third in 2020 [16].

Table 1. GDP growth will be negative in most Central Asia countries in 2020 (Source: IMF Regional Economic Outlook Update: Middle East and Central Asia,

https://www.imf.org/en/Publications/REO/MECA/Issues/2020/07/13/regional-economic-outlookupdate-menap-cca\#report).

\begin{tabular}{|c|c|c|c|c|}
\hline & $\begin{array}{c}\text { GDP growth } \\
\mathbf{2 0 1 9}\end{array}$ & $\begin{array}{c}\text { GDP growth } \\
\text { forecast 2020 } \\
\text { (estimates as of } \\
\text { October 2019) }\end{array}$ & $\begin{array}{c}\text { GDP growth } \\
\text { forecast 2020 } \\
\text { (estimates as of } \\
\text { May 2020) }\end{array}$ & $\begin{array}{c}\text { GDP growth } \\
\text { forecast 2021 } \\
\text { (estimates as of } \\
\text { April 2020) }\end{array}$ \\
\hline Afghanistan & $+3 \%$ & $+3.5 \%$ & $-3 \%$ & $+4.5 \%$ \\
\hline Kazakhstan & $+4.5 \%$ & $+3.9 \%$ & $-2.5 \%$ & $+4.1 \%$ \\
\hline Kyrgyzstan & $+4.5 \%$ & $+3.4 \%$ & $-4 \%$ & $+8.0 \%$ \\
\hline
\end{tabular}




\begin{tabular}{|c|c|c|c|c|}
\hline Mongolia & $+5.1 \%$ & $+5.4 \%$ & $-1 \%$ & $+8 \%$ \\
\hline Tajikistan & $+7.5 \%$ & $+4.5 \%$ & $-2 \%$ & $+5.5 \%$ \\
\hline Turkmenistan & $+6.4 \%$ & $+6 \%$ & $+1.8 \%$ & $+6.5 \%$ \\
\hline Uzbekistan & $+5.4 \%$ & $+6 \%$ & $+1.8 \%$ & $+7.0 \%$ \\
\hline
\end{tabular}

The effects of the COVID-19 crisis will slow down the economic growth experienced by the country to an expected $+1.8 \%$ in 2020 . Real GDP growth had accelerated slightly in 2019 to $5.6 \%$, supported by a $34 \%$ year-on-year increase in investment, largely driven by direct lending to SOEs, and growth in the agricultural and manufacturing sectors. Since 2016, growth has been supported by an active programme of economic reforms, including currency liberalization. Despite these reforms, FDI inflows remain low, at $1.2 \%$ of GDP in 2018, though trends prior to the COVID-19 suggested that foreign investment had begun to increase. Uzbekistan has one of the more diversified export baskets in Central Asia and trades with a wider range of countries than most of its regional peers. Strong export growth and remittance contributions have contributed to a narrowing of the current account deficit from $7.1 \%$ in 2018 to $4.2 \%$ in 2019 . The government response to the COVID-19 will probably increase the account deficit, while growth of the domestic economy is likely to slow.

\section{Short-term indicators}

Growth for 2020 is expected to slow markedly, to $1.8 \%$, assuming that the pandemic and required containment efforts peak in the second quarter for most countries and recede in the second half. Impacts on the economy are very large, in particular due to the size of the informal sector. According to the Ministry of Labour, only 5.7 million people are employed in the formal sector out of 19 million in the labour force, leaving a large amount of people vulnerable to the slowdown.

\section{Public finances}

The government indicated that if export revenues decrease due to falling gas prices (following lower oil prices) and the devaluation of the Russian and Kazakh currencies, subsequent losses to the state budget (about USD 1.1bn according to official figures) should be fully compensated by higher gold prices. A law to review of public budget and priorities expenditures is being prepared to help stabilize the budget and mitigate the negative impact of the pandemic.

\section{Financial markets}

The exchange rate depreciated by $6.5 \%$ between 28 February and mid-April. The currency has been strongly supported by the Central Bank's sale of foreign currency which should increase by $30 \%$ compared to last year, on the back of higher gold prices.

\section{Monetary policy}

The Central Bank has decreased its policy rate by 1 p.p. mid-April to $15 \%$, but the rate remains at a very high level to contain inflation amid external uncertainty due to the coronavirus outbreak and the expected effects of price liberalization for selected goods and 
services. The bank also has offered several targeted refinancing operations for commercial banks (350bn UZS), but did not change regulatory, capital or liquidity requirements.

\section{Economic support measures}

An Anti-Crisis Fund of UZS 10 trill. Sum - EUR 950 m - (1.5\% of GDP) has been set up to cover immediate medical and quarantine expenses, increase the number of social benefit recipients, provide liquidity, interest subsidies, loan repayment deferrals, guarantees to businesses, and finance infrastructure work in regions to sustain employment. The Fund also finances an allocation of UZS 200bn (EUR $19 \mathrm{~m}$ ) to the Public Works Fund to support employment and the construction of additional infrastructure, and of UZS 500bn (EUR 47m) to the State Fund for Entrepreneurship Support to assist job creations by businesses. The State Fund for Business Development Support will also provide businesses with partial compensation for loan interest expenses and a guarantee in the amount of up to 50 percent of the loan amount. A series of fiscal measures have been set up in addition. In particular, tax deferrals for most affected SMEs and individual entrepreneurs until October; a moratorium on tax audits until the end of 2020 and on bankruptcy procedures until October; a deferral of the scheduled increase of tax rates; an extension of tax declaration submission until October; an ease of VAT calculation and payment requirements for small businesses; no excise tax and customs duties for the import of 20 types of basic consumer goods until the end of the year; and the suspension of rent payments for the use of state property by business entities that have been forced to suspend their activities. Several sectors have received specific support and funding, including the construction sector which was allocated a further UZS $3 \operatorname{trn}$ (EUR $320 \mathrm{~m}$ ). Finally, for households, parents are granted a $100 \%$ temporary disability benefit, and child care benefits and material assistance are automatically extended for all beneficiaries. Social safety net coverage has been overall expanded by $10 \%$.

\section{DE confinement}

By the end of April, selected enterprises (e.g. construction materials, auto parts stores, large car services, insurance companies, notaries, craftsmen, agricultural businesses, and chain stores) were permitted to gradually resume operations. According to official numbers, 5400 out of the 14000 companies in the Tashkent region whose activities had been strictly checked, could resume their activities. A similar easing of economic activity occurs also in regions, based on a color code assessing the severity of the virus in specific regions and cities. In particular, freight traffic for fresh agricultural goods between the regions and the capital Tashkent was allowed to resume to mitigate the financial losses of agricultural companies. Individuals also benefit from a gradual easing of rules, allowing for short outdoor activities with children, and a restricted use of cars for essential movements (e.g. going to work, buying essentials or medicine). Mid-May, the government has developed an economic post-crisis action plan for businesses and households, providing for an extension of most economic, tax, and social measures adopted during the outbreak.

Virtually all Central Asian governments have prepared and implemented specific policy responses to address the health situation and fight the economic consequences of the pandemic . Several have designed dedicated national plans or funds to gather and channel financial flows, including Kazakhstan, Kyrgyzstan, and Uzbekistan.

Most of the region's governments have developed specific measures aimed to support business activities. They have increased the liquidity and credit lines for businesses through dedicated funds and commercial banks. Some have also supported deferral of loan repayment from banks. Another policy response relates to taxation, with governments postponing tax 
declarations, deferring tax payments, suspending tax audits or exempting firms from social contributions, among other measures.

The drop in commodity prices and exports, as well as the uncertain economic outlook, have led central banks in the region to adopt differing policy responses. Uzbekistan has adopted a third approach, allowing for targeted and eased refinancing operations of commercial banks, while keeping its policy rate unchanged at a record high.

Several countries have called for emergency financial support from international partners and have received emergency funding to mitigate the immediate economic impact of the COVID-19.

During the course of March and April 2020, the Government of the Republic of Uzbekistan (the "Government") has implemented a number of laws and measures (Table 1), including:

- 19 March 2020: Presidential Decree No. UP-5969 “On priority measures to mitigate the negative impact of coronavirus pandemic and global crisis to the economic sectors" (the "Decree 5969");

- The establishment of the Special Anti-crisis Fund of 10 trillion Uzbek Soums ("UZS") (equivalent of 1 billion US Dollars ("USD")) at the Ministry of Finance;

- 3 April 2020: Presidential Decree No. UP-5978 "On additional measures to support the public, economic sectors and businesses during the period of coronavirus pandemic" (the "Decree 5978"); and

- 27 April 2020: Presidential Decree No. UP-5986 "On additional measures to support the public and business entities during the coronavirus pandemic" (the "Decree 5986").

- These measures provide certain guarantees and protections, including deferred tax payments, decrease of tax rates, tax related waivers and exemptions, as well as liquidity support measures.

Table 2. The key applicable measures to support the liquidity of companies and ensure business continuity (Source: Adopted by author).

\begin{tabular}{|l|l|l|}
\hline \multicolumn{1}{|c|}{ Support measures } & \multicolumn{1}{|c|}{ Beneficiaries and } & \multicolumn{1}{c|}{ Effective period } \\
\hline Deferrals of loan repayments & $\begin{array}{l}\text { all businesses } \\
\text { individuals }\end{array}$ & until 1 October 2020 \\
\hline $\begin{array}{l}\text { Suspension of initiating and declaring } \\
\text { bankruptcy of businesses by state } \\
\text { authorities }\end{array}$ & all businesses & until 1 October 2020 \\
\hline Extension of deadline for a 2019 audit & all businesses 2020 \\
\hline $\begin{array}{l}\text { Reduction of tax rate by 50\% for } \\
\text { agricultural use of water resources }\end{array}$ & $\begin{array}{l}\text { all businesses and } \\
\text { individuals }\end{array}$ & $\begin{array}{l}\text { from 1 January 2020 to 31 } \\
\text { December 2020 }\end{array}$ \\
\hline $\begin{array}{l}\text { Interest free deferral of payments of } \\
\text { sales tax, property tax, land tax, and } \\
\text { tax for use of water resources }\end{array}$ & all businesses & $\begin{array}{l}\text { six months } \\
\text { application }\end{array}$ \\
\hline $\begin{array}{l}\text { Exemptions from customs payments } \\
\text { including VAT for import of } \\
\text { construction materials, express tests } \\
\text { for coronavirus, as well as special } \\
\text { equipment and consumable spare } \\
\text { parts to be used for the construction } \\
\text { and functioning of medical and } \\
\text { quarantine facilities to combat } \\
\text { coronavirus pandemic }\end{array}$ & all businesses & until 31 December 2020 \\
\hline $\begin{array}{l}\text { Exemption from applying a deemed } \\
\text { interest rate (15\%) for interest-free } \\
\text { loans }\end{array}$ & all businesses & until 31 December 2020 \\
\hline
\end{tabular}




\begin{tabular}{|c|c|c|}
\hline $\begin{array}{l}\text { Income tax deduction and exemption } \\
\text { from VAT for businesses that } \\
\text { contribute to special charity } \\
\text { foundations and their regional } \\
\text { structures }\end{array}$ & all businesses & $\begin{array}{l}\text { from } 1 \text { April } 2020 \text { to } 1 \\
\text { October } 2020\end{array}$ \\
\hline Suspension of tax audits & all businesses & until 1 January 2021 \\
\hline $\begin{array}{l}\text { Suspension of increased land tax and } \\
\text { property tax rates applicable for } \\
\text { unused non-residential buildings and } \\
\text { production facilities }\end{array}$ & all businesses & $\begin{array}{l}\text { from } 1 \text { April } 2020 \text { to } 31 \\
\text { December } 2020\end{array}$ \\
\hline Suspension of tourist fee accrual & hotels & $\begin{array}{l}\text { from } 1 \text { April } 2020 \text { to } 1 \\
\text { July } 2020\end{array}$ \\
\hline $\begin{array}{l}\text { Suspension of penalties for overdue } \\
\text { receivables from foreign trade } \\
\text { operations }\end{array}$ & Exporters & until 1 October 2020 \\
\hline $\begin{array}{l}\text { Permission for wholesale of medical } \\
\text { drugs and medical products at } \\
\text { pharmacy outlets }\end{array}$ & $\begin{array}{l}\text { manufacturers of medical } \\
\text { products }\end{array}$ & until 1 October 2020 \\
\hline $\begin{array}{l}\text { Permission to pay VAT on a quarterly } \\
\text { basis }\end{array}$ & $\begin{array}{l}\text { VAT payers with } \\
\text { monthly turnover not } \\
\text { exceeding UZS } 1 \text { billion } \\
\text { (USD } 1 \text { million.) }\end{array}$ & $\begin{array}{l}\text { from } 1 \text { April } 2020 \text { to } 31 \\
\text { December } 2020\end{array}$ \\
\hline $\begin{array}{l}\text { Exemption from property tax and } \\
\text { land tax }\end{array}$ & $\begin{array}{l}\text { tour operators, travel } \\
\text { agents and hotels, } \\
\text { "Uzbekistan Airways", } \\
\text { "Uzbekistan Airports", } \\
\text { "Uzaeronavigation } \\
\text { Center" }\end{array}$ & $\begin{array}{l}\text { from } 1 \text { April } 2020 \text { to } 31 \\
\text { December } 2020\end{array}$ \\
\hline $\begin{array}{l}\text { Reduction of social tax rate from } 12 \text { - } \\
25 \% \text { to } 1 \%\end{array}$ & $\begin{array}{l}\text { tour operators, travel } \\
\text { agents and hotels, } \\
\text { "Uzbekistan Airways", } \\
\text { "Uzbekistan Airports", } \\
\text { "Uzaeronavigation } \\
\text { Center" }\end{array}$ & $\begin{array}{l}\text { from } 1 \text { April } 2020 \text { to } 31 \\
\text { December } 2020\end{array}$ \\
\hline $\begin{array}{l}\text { Interest-free deferral plan for: } \cdot \text { sales } \\
\text { tax, property tax, land tax, and tax for } \\
\text { the use of water resources - with their } \\
\text { subsequent payment in equal } \\
\text { installments within } 12 \text { month; due } \\
\text { social tax being paid in equal } \\
\text { installments within six months. }\end{array}$ & small businesses & until 31 December 2020 \\
\hline
\end{tabular}

\section{Measures supporting the business continuity}

The Decree 5978 provides that, for the period until 1 October 2020, the State Fund for Entrepreneurship Support will provide:

a) a surety to secure the loans provided to businesses with positive credit history up to $75 \%$ of the relevant loan amount, but not more than UZS 10 billion (equivalent of USD 10 million);

b) a compensation for interest expenses on loans granted to businesses in national currency; provided that the interest rate does not exceed 1.75 times the refinancing rate of the Central Bank; and a waiver of restriction on simultaneous provision of surety and compensation to the same borrower. 
The Fund for Reconstruction and Development of the Republic of Uzbekistan has extended the maturity periods of loan resources, allocated to commercial banks for refinancing such loans, which have been deferred for repayment.

The Ministry of Finance has been instructed by the Government to extend the terms of sovereign guarantees granted under relevant loans, the payments of which has been extended.

The Ministry of Finance has also been instructed the Government to provide monthly support, on the account of the Anti-Crisis Fund, to local state authorities to replace the shortfalls incurred as a result of deferrals (installment plans) for the payments of property tax, land tax and tax for the use of water resources.

For the period until 1 October 2020:

a moratorium has been placed in relation to initiating bankruptcy procedures and declaring bankruptcy of businesses faced with financial hardships due to quarantine measures;

the deadline for conducting an audit for the financial year 2019 for businesses subject to mandatory audit has been extended; and companies are allowed to hold their annual general meetings of shareholders for 2019, including by means of video conferencing.

\section{Tax benefits}

The Decree 5969, the Decree 5978, and the Decree 5986 (together the "Decrees") have introduced the following tax reductions (benefits) for businesses:

for the period from 1 April 2020 to 1 October 2020:

- the minimum amount of social tax for individual entrepreneurs is reduced to $50 \%$ of the base calculated amount ("BCA") per month;

- the amount of mandatory payments for wholesalers of alcoholic beverages is reduced from 5 to $3 \%$; and fees for the right to retail sale of alcoholic products by catering enterprises are reduced by $25 \%$ of the amounts set under law.

- tax rates for the use of water resources in volumes required for irrigation of agricultural land are reduced by $50 \%$ of the rates set for 2020 .

This is an important measure given that Uzbekistan's economy is significantly based on agriculture;

- imposing interest on property tax, land tax and tax for the use of water resources, as well as enforcement of tax debt collection in relation to businesses experiencing temporary hardships has been suspended;

- businesses have been provided with tax deferral (installment) plan for the due payments of property tax, land tax and tax for the use of water resources without any interests applied for a six-month period based on relevant application;

- for the period from 1 April 2020 to 31 December 2020, VAT payers with monthly turnover not exceeding UZS 1 billion (the equivalent of USD 1 million) and applying electronic invoices are entitled to calculate and pay VAT on a quarterly basis;

- calculations of a fixed personal income tax and social tax for individual entrepreneurs affected by the quarantine measures have been suspended for the period of the quarantine measures, subject to notifications of the relevant tax authority through the online personal tax platform;

the Government has granted the right to interest-free deferral (installment plan) for taxes until 31 December 2020 for small businesses suspended and (or) whose revenue has dropped by more than $50 \%$ compared to monthly average for the first quarter of 2020 , with notification of tax authorities: 
- without submitting an application to local authorities on due payments of sales tax, property tax, land tax, and tax for the use of water resources - with their subsequent payment in equal installments within 12 months;

- due social tax being paid in equal installments within six months.

In addition, import of construction materials, as well as special equipment and consumable spare parts to be used for the construction and functioning of medical and quarantine facilities to combat coronavirus pandemic are exempted from customs payments, including value-added tax ("VAT"). Import of express tests for coronavirus has been exempted from customs fees. These exemptions apply until 31 December 2020.

Until 31 December 2020, if a loan is obtained at no interest, the borrower has been allowed not to include a 'deemed interest' (considered as income from such loan and interest calculated applying the Central Bank's refinancing rate) in accruing the corporate income tax and sales tax. This exemption provides businesses with access to tax-free loans which is very important during the crisis.

The Government, under the Decree 5986, has also provided certain tax benefits for businesses that contribute to special foundations and their regional branches, as noted below, for the period from 1 April 2020 to 1 October 2020:

- gratuitous transfers to the "Mahalla" ("Community") Charitable Public Foundation of Uzbekistan, the Kindness and Support Foundation, "Uzbekistan Mehr-shafqat va salomatlik ("Mercy and Health")" Public Foundation, as well as donations to individuals in need of social support (as filed so by local authorities) of:

- cash and goods (services) shall be considered as deductible expenses in calculating income tax; and goods (services) shall be exempt from VAT and not considered for the purposes of sales tax.

The Government has established that the gratuitous assistance (cash, goods/services) provided by public foundations, as noted above, as well as donations by legal entities and/or individuals shall not be considered as income for individuals in need of social support (as filed so by local authorities) receiving such donations.

\section{Conclusion}

The outbreak of COVID-19 has required governments to move rapidly to expand the capacity of their healthcare sectors and cushion the economic effects of containment policies and their effect on consumption. Policy interventions must aim to sustain household income, business activity, and the macroeconomic fundamentals to allow for a quick and sustainable recovery. While these measures imply substantial costs to public finances, the cost of inaction - a longterm destruction of productive capacity - would be even higher.

The global economic impact of COVID-19 is weakening the Uzbek economy, in particular due to a drop in prices and volumes of natural gas supplies to Russia and China, a reduction in the inflow of remittances from migrant workers in Russia (about USD 1.3 billion), the partial closure of the borders of Kazakhstan, which for Uzbekistan is the main export market for fresh agricultural products, and the burden on the state budget created by the announced support measures. At the same time, the government offered to join the Eurasian Economic Union (EAEC) as an observer. For the economy to survive this shock, the government will have to strike the right balance between priority measures to accelerate recovery and the continuation of reforms aimed at preserving national growth potential and diversifying the economy, including attracting investment and improving the legal environment for entrepreneurship. In addition, new priorities related to digitalization can support the use of new economic opportunities as well as the quality of public services.

This study was conducted to examine the impact of COVID-19 outbreak on SMEs operating in Uzbekistan in order to assist policymakers and practitioners in streamlining the 
strategies to ease the burden of the current crisis on these businesses. Our findings underline several issues faced by SMEs due to the current pandemic.

\section{Reference}

1. https://www.oecd-forum.org/users/406151-lamia-kamal-chaoui/posts/rescuing-smesfrom-the-covid-storm-what-s-next

2. http://www.oecd.org/coronavirus/\#

3. https://www.wto.org/english/news_e/pres20_e/pr858_e.htm

4. https://nextcity.org/daily/entry/cities-starting-grapple-with-small-business-declinesdue-to-virus-

outbreak?utm_source $=\mathrm{Next}+\mathrm{City}+\mathrm{Newsletter \& utm \_ campaign}=5 \mathrm{~d} 645 \mathrm{c} 1081$ -

EMAIL_CAMPAIGN_2019_02_21_05_47_COPY_01\&utm_medium=email\&utm_ter $\mathrm{m}=0$ fcee $5 \mathrm{bf} 7 \mathrm{a} 0-5 \mathrm{~d} 645 \mathrm{c} 108 \overline{1}-4 \overline{3} 981729$

5. Word Economic. World economic prospects monthly. Economic Outlook 44(S2), 1-33 (2020)

6. Asian development outlook: What drives innovation in Asia? Special topic: The impact of the coronavirus outbreak (Asian Development Bank. Manila, Philippines, 2020)

7. Investment trends monitor: Impact of the coronavirus outbreak on global FDI (United Nations Conference on Trade and Development, 2020) https://unctad. org/en/PublicationsLibrary/diaeinf2020d2_en.pdf?user $=1653$

8. The Covid-19 shock to developing countries: Towards a "whatever it takes" programme for the two-thirds of the world's population being left behind (United Nations Conference on Trade and Development, 2020)

9. ILO (2020a). COVID-19 and the world of work: Impact and policy responses. ILO Monitor $\left(1^{\text {st }}\right.$ ed.). International Labour Organization.

10. COVID-19 and the world of work: Updated estimates and analysis. ILO Monitor (International Labour Organization, 2020)

11. East Asia and Pacific in the time of COVID-19. East Asia and Pacific economic update (World Bank, Washington, DC, 2020)

12. Assessment report on impact of COVID-19 pandemic on Chinese enterprises (United Nations Development Programme, 2020)

13. South Asia economic focus, spring 2020: The cursed blessing of public banks (World Bank, Washington, DC, 2020)

14. Limiting the Economic Fallout of the Coronavirus with Large Targeted Policies, https://blogs.imf.org/2020/03/09/limiting-the-economic-fallout-of-the-coronaviruswith-large-targeted-policies/?utm_medium=email\&utm_source=govdelivery

15. A. Duarte Alonso, N. Sakellarios, N. Alexander, S. O'Brien, Asia Pacific Journal of Marketing and Logistics 30(2), 276-296 (2018)

16. COVID-19 crisis response in Central Asia - OECD, https://www.oecd.org/eurasia/competitiveness-programme/central-asia/COVID-19crisis-response-in-Central-Asia-Russian.pdf 